\title{
The Principle of Indemnity in Valued Marine Policies
}

\author{
Aboutaleb Bazvand \\ Ph.D. scholar, Law Department, Osmania University, India
}

\begin{abstract}
To consider people are encountering many perils that threat their health, life and property as such people interested to insure their belonging and get rid of risk and danger to live and work tranquility. As stated that marine insurance is the oldest branch of insurance and now days most of trade is by sea transportation and economic of countries are rely on export and import which are strongly depend on marine insurance, because the marine insurance plays an important role in the world and has high position. And how marine insurance includes the loss and which losses are not included considering one of the most important subjects for that person who wants to insure their life and property. The paper intends to give a wide-ranging account of the principal of indemnity in a marine insurance and analyses which losses are not included by a marine insurance contract. A policy of assurance has long held is not perfect contract of indemnity. This paper attempt is to examine this truism in the context of value policies.
\end{abstract}

Keywords: Marine insurance, Indemnity, Marine policy

\section{Introduction}

The fundamental principles of insurance law are a distinctive admixture of contract, law and practice. The base of marine insurance shows how the contract embodied in the policy of assurance is privileged and is advanced by the Marine Insurance Act 1906 and market practice. The parties to the policy, the assured and the insured, are given comparative freedom to case of the agreement to their particularity. Yet, this freedom is not without restriction and constrain. Compulsory rules of public policy have significant roles. These rules work for binding this freedom and bring a sense of homogeneity to what could if not be a many different kinds of contracts. In insurance practice conspicuous public policy concerns against take advantage of centered on the forbiddance of gaming and wagering, illegal adventure and cheating act prevent any policy arrangements which are regarded too illicit to be certified.

In a context which signally notifies that it is overseen by the concept of indemnity, public policy efforts are servants to this governance generating clashes with the independence of the parties to contract. The theorist and practitioner are and so demonstrated with different microcosms in which this battle between the contracting parties and public policy is functional in this article the conflict between the marine insurance law's broader concern of join to the concept of indemnity as rely on public policy and the freedom to contract assumed in the appreciated policies will be defined and studied. In the context of appreciated policies, where the parties reach agreement the indemnity to be paid between themselves faith often false is gratuity of their agreement on this matter. The law offers to support such agreements so long as they do not approach any of the public policy stimulant set forth above. Hence, the principle of indemnity takes a backseat in attribute of the parties' freedom of contract. Given the main concern in which the concept is regarded seemingly surprising. Yet, the law of marine insurance has a situation toward sensibility and in this meaning it is documented that the objective to strictly append to the indemnity principle is incongruous with the urgency of practice. The result has been that the assurance policy is regarded as an incomplete contract of indemnity (D Rose 783).

Marine insurance is an episode of insurance with a long history. The purpose of insurance is not just ship, cargoes and other ambulatory property on the sea, but also the freight, rate, commission, estimated interests and third party liabilities because of the maritime perils.

Marine insurance began early in Western countries, but its contents changed fast along with its appliance. The studies of marine insurance commonly concern its juristic perspective (Martine Remond-Gouilloud 2). 


\section{History of Marianne Insurance:}

Marine Insurance is not a new concept. Its existence can be traced back to more than a few centuries. Demands concerning it have naturally been about to happen for many years and the law in relation to it had taken a definite form much prior to 1906 when the English Marine Insurance Act was passed with an observation to codify that law.

Opposing to general opinion, Lloyds' of London was not considered the first group of people to propose insurance for maritime commerce. The first kind of marine insurance goes back to the year $3000 \mathrm{BC}$ when Chinese merchants send out their shipments amongst quite a lot of ships in order that to abridge the risk of damage to the products. The most basic account of insurance came in the form of "bottomry", a monetary payment that watch over merchants from dues if merchandise is lost or damaged.

Another form of initial insurance was the "general average". Throughout cargo shipments in 916 BC, a merchant would go along with his cargo to understand that it was not jettisoned, or voluntarily thrown overboard by the sailor in times of a storm or sink age. To protect against this mutual interest of safety and quarreling among merchants, the Rhodium's began the 'general average', which in theory signify that a person would be reimbursed throughout pro rata contributions of other merchants if their goods were jettisoned during shipment.

From the 11th century to 18th century, a few more breakthroughs happened in marine insurance. In 1132, the Danish began to reimburse those who practiced loss at sea. In 1255, 'insurance premiums' were practiced for the first time as the Merchant State of Venice coalesce these premiums to indemnify loss because of portray, spoilage, or pillage. The prime marine insurance policy was commenced in 1384 in an effort to include bales of fabric traveling to Savona from Pisa, Italy. Within the next century, merchants from Lombard started the first insurance operation in London. Finally, in 1688, Lloyd's of London, named after Edward Lloyd, initiated the risky business of insurance underwriting. From a Coffee house in London, it has currently grown to become the main marine insurance underwriters in the world (3).

\section{Marine insurance:}

Marine insurance include the loss or damage of ships, cargo, terminals, and any transport or cargo by which property is transported, obtain or held between the points of origin and ultimate objective. Cargo insurance -argued here is a subbranch of marine insurance, even though Marine also involves Onshore and Offshore exposed property, (container terminals, ports, oil platforms, pipelines), Hull, Marine Calamity, and Marine Liability, When post or nuncio transports goods, shipping insurance is practiced instead (Franklin 273-278).

\section{Marine insurance contract:}

A number of the law of marine insurance is in nature pure commentary of the contract included in the usual form of marine policy. The basic norm of a contract of insurance is that the indemnity recoverable from the insurer is the monetary loss suffered by the assured under the contract. Hence, as per the approval, a contract of marine insurance is a contract whereby the insurer pledges to indemnify the assured, in style and to a degree thus agreed, against marine losses, that is to say, the losses event to marine adventure (Cases and Materials on Marine Insurance Law By Susan Hodges).

A contract of marine insurance my, by its express terms, or by use of trade, be expanded so as to protect the assured against losses on inland waters or any land risk that may be accidental to any sea voyage. Where a ship in period of building, or the commissioning of a ship, or any adventure resembling a marine adventure, is included by a policy in the shape of a marine policy, the provisions of this Act, in so far as enforceable, shall apply thereto; but, except as by this section arranged, nothing in this Act shall moderate or influence any rule of law enforceable to any contract of insurance other than a contract of marine insurance as defined, by the Act (Cases and Materials on Marine Insurance Law By Susan Hodges ).

The formal instrument incorporating the contract of marine insurance is called "the policy"; and " the slid" or "covering note", is the informal memo that is settle when the contract is got involved. The subject insured and the consideration for the insurance are in that order identified as "the interest insured" and "the premium". The one who is covered is "the assured" and the other party is called "the insurer" or "the underwriter" so called since he pledge or underwrites the policy. 
"Loss" comprises damage or detriment along with actual loss of property gets up from maritime perils. "Maritime perils" indicates the perils consequent on, or incidental to, the aviation of the sea, that is, perils of the sea, fire, war perils, pirates, rovers, thieves, captures, usurpation, restraints, and detainments of princes and peoples, jettisons, barratry, and any other perils (War, Terror and Carriage by Sea By Keith Michel 105).

Marine insurance losses will be included as follow:

General average: Concerning on The law of General Average shows it is relevant to a legal principle of maritime law to all parties in a sea venture, relatively share any losses bring about a voluntary victim of part of the ship cargo to protect the whole in an emergency. The fundamental principles of General Average is that a party who has suffered some huge expenses or loss to save property belonging to others has the right of compensation for its loss from all parties to the voyage who have profited from it.

\section{Marine Insurance Considerations:}

\section{Total Loss}

Within marine insurance a total loss can take one of two forms, either actual total loss or constructive total loss. In both situations the subject matter insured is regarded completely lost to the assured and over that loss the assured is authorized to the full-agreed value under the policy. As indicated the agreed value in the policy is representative of the insurable value of the subject matter under the policy. It is this to which the assured is authorized in face of a total loss regardless of whether the policy is valued or unvalued. The conclusiveness of the agreed value in this situation estops the assured or insurer from disputing (Jonathan Gilman, Robert Merkin, Claire Blanchard, Mark Templeman) said value. So long as the value agreed has been paid to the assured in this condition it cannot be denied that a full indemnity has be given under the policy (Gilman, John, Robert Merkin and Claire Blanchard )

\section{Particular Loss}

Marine insurance supply under which damages or expenditure incurred by a shipper (whose cargo is uncovered to a danger) are borne by that shipper only. Such damages or expenditures happen by direct hurt to the ship and/or cargo, or in a course of action to avoid primary or further hurt to them. Specific average, like general-average is independent of the insurance cover bought for the cargo. In its place, it gets up out of the contract between the cargo-owner and the shipowner. Nowadays, greatly is substituted by the linked institute cargo clause.

\section{Particular average loss}

A specific average loss is a partial loss of the subject-matter insured, led by a risk insured against, and which is not a general average loss.

Expenses incurred by or on regard of the assured for the safety or protection of the subject-matter insured, other than general average and recue charges, are called certain charges. Specific charges are not involved in specific average (Francis Rose 345).

\section{Actual total loss}

Actual total Loss is clarified in section 57(1) of the Marine Insurance Act 1906. This provides: Where the subject-matter insured is demolished, or so damaged as to stop to be a thing of the type insured, or where the assured is irretrievably divested thereof, there is an actual total loss. Templeman on Marine Insurance (Lambent 1986) arranges for different examples, involving destruction by fire, sinking in a storm by sea, and sinking in deep water after a collision. With continuous developments in technology, it turn out to be ever more problematic to state with certainty that, in the lack of complete and absolute destruction, a subject-matter does indeed constitute an actual total loss; it has turned into more problematic to distinguish between an actual and a constructive total loss in cases where the subject-matter is demolished but there is a technical risk of rebuilding. The example of irretrievable privation is almost certainly even more problematic. Templeman (Lambent 1986) states that: "irretrievable deprivation involves capture or usurpation, and connote that although the subjectmatter insured may be actually in existence, the assured will never again recapture possession of it: for example, capture 
by enemy in time of war and condemnation as lawful reward." The Court of Appeal in the recent case of Masefield AG v Amylin Corporate Member asked whether a loss by piracy could lead to an actual total loss (Gotthard Gauci 118)

Constructive total losses: is The introduction to the Marine Insurance Act 1906 gives that the objective of the legislators was to codify the law with regard to marine insurance, and in Section 60 designate a constructive total loss in the following words: (1) Depending on any express provision in the policy, there is a constructive total loss where the subject-matter insured wisely abandoned due to its actual total loss rising to be expected, or since it could not 22 See Masefield (John Dunt 566) total losses and risk of piracy in English marine insurance 119 be immune from actual total loss without an expenditure, which would transcend its value when the expenses had been incurred. (2) Specifically, there is a constructive total loss - (i) Where the assured is divested of the possession of his ship or goods by a peril insured against, and (a) it is unseemly that he can recover the ship or goods, as the case may be, or (b) the charge of recovering the ship or goods, as the case may be, would transcend their value when recovered; or (ii) In the case of damage to a ship, where ship is so damaged by a peril insured against, that the charge of repairing the damage would transcend the value of the ship when repair. In calculating the cost of repairs, no fraction is to be made regarding general average share to those repairs payable by other revenues, but account is to be taken of the expenditure of future rescue operations and of any future general average contributions to whom the ship would be pledge if remade; or (iii) concerning damage to goods, where the expense of repairing the damage and transportation of the goods to their endpoint would trespass their value on arrival. Details about the process for claiming a constructive total loss, specially the general obligation of providing a announcement of quit, are given in section 62 of the Marine Insurance Act 1906.27 It is sturdily arguable that the section 60(2)(I)(a) regard to dissonance of recovery [within a reasonable time] does not sit comfortably with the situation of reasonable quit due to an actual total loss appearing to be inevitable. Yet, this view can be avoided by giving the term "unavoidable" an expansive commentary (G Gauci)

In case of total loss of actual loss and constructive loss of the entire sum insured or the insurer is obliged to pay the price completely.

Before talking about F.P.I and W.A that it has to be indicated very significant issue that when insured practice each condition, insurance coverage is not restricted to loss in the marine insurance agreement but insured and insurer by former agreement or placed in the particular conditions of the insurance police, are able to meet their obligation to adjust (lessen, or enhance) them.

\section{Free particular average (F P I)}

Marine insurance provision which restricts the liability of an insurance company to only those losses that transcend a designated percentage of the value of the goods. It is similar to the deductible clause involved in other types of insurance, but is not valid where a cover for total loss is in force. FPA conditions are applied where the goods are exceedingly subject to damage, or are rendered in effect worthless from exposure to water or heat (David, P., Stewart)

\section{FPA conditions loss coverage}

Harsh weather, lightning, barratry of the mariners or masters, assailing thieves

Stranding, burning, sinking, collision, fire while on deck

Stranding, burning, collision while under deck

Explosion or fire

Stranding, sinking or burning of the ship or the craft

Collision or crash of a land or air conveyance

Collision or a marine conveyance with any external object like ice-berg other than water
Cover only for total loos

Covered

Covered

Covered

Covered

Covered

Covered 
Free of particular average (FPA) indicates a marine insurance term meaning that the assurer will not permit payment for partial loss or damage to cargo shipments except in certain position, such as stranding, sinking, collision or fire (Thomas A. Cook 310).

There are two different types of Total Loss defined in the Marine Insurance 1906 Act (16) while it includes only partial losses in some situation. The central issue is whether the policy is a Free of Particular Average-English Conditions policy or a Free of Particular Average-American Conditions policy. Under an American Conditions policy, partial losses are included only if they out come directly from a fire, a stranding, a sinking, or a collision. Under an English Conditions policy, the partial losses are included if they occur on the same voyage that a fire, a stranding, a sinking, or a collision happens, without this risk having directly led to the loss (International logestics152).

\section{Damage insurance outside of the commitment of the insurance policy (F PA)}

In the FPA insurance some damages are outside and exception of insurance contract such as: particular damages

Deduct or lack of handovers from one pallet, boxes, packages, damage led tothe delay in the shipment insurance even though insurance might be postponed because of a risk that is stated in insurance contract, inherent defect goods, for instance compactness weight fraction damages the event of normal ordinary, damages caused by the action of vermin such as mice, insects and damages that overtly are due of war, strikes, riots and civil strife have caused.

With Average or WA coverage:

This policy plays a role of an extension of the FPA to include the damages happened by harsh weather. Eventually in a number of cases the FPA and WA may be expanded to include non-delivery, theft and pilferage.

\section{Comparisons:}

\begin{tabular}{|c|c|c|c|}
\hline LOSSES & FPA & WA & ALL-RISK \\
\hline Sinking & Covered & Covered & Covered \\
\hline Stranding & Covered & Covered & Covered \\
\hline Collision & Covered & Covered & Covered \\
\hline Burning & Covered & Covered & Covered \\
\hline Bursting of boilers & Covered & Covered & Covered \\
\hline Vessel Management Errors & Covered & Covered & Covered \\
\hline Defects machinery or hull & Covered & Covered & Covered \\
\hline Jettison & Covered & Covered & Covered \\
\hline Perils or harsh weather & Covered & Covered & Covered \\
\hline Seawater & Covered & Covered & Covered \\
\hline Fresh water & Uncovered & Uncovered & Covered \\
\hline Mud, grease or hook damage & Uncovered & Uncovered & Covered \\
\hline Fault storage by the carrier & Uncovered & Uncovered & Covered \\
\hline Non-delivery of the entire package & Uncovered & Uncovered & Covered \\
\hline If the entire consignment is stolen & Uncovered & Uncovered & Covered \\
\hline Leakage & Uncovered & Uncovered & Covered \\
\hline
\end{tabular}




$\begin{array}{llll}\text { Pilferage } & \text { Uncovered } & \text { Uncovered } & \text { Covered } \\ \text { Breakage } & \text { Uncovered } & \text { Uncovered } & \text { Covered }\end{array}$

* Only total losses and not partial losses -Certain deprivation and alterations may happen in coverage polices depending upon the nature of the shipment.

\section{Freight}

Freight insurance is a policy that looks after the policyholder from the loss of goods all through shipment. It is also identified as cargo insurance. Freight insurance preserves the owner or consignor of goods for feasible physical loss or damage from outside factors within shipping. The insurer would repay the policyholder for the value of the goods if they incur damage or demolish while in the hands of the shipper. It is often available from the shipping company itself, or it may be bargained from a third party insurer too.

\section{Goods}

Under the MIA 1906, partial loss of goods is regulated by section 71. As is the case regarding freight, the indemnity payable to the guaranteed is also dividing respecting to the agreed value. Under the section 71 a modification is made between goods which are to some extent lost due to part of a whole shipment being totally lost or due to apart or the whole of the goods being damaged but not a total loss. Where on earth a part of the goods turns into a total loss, the measure of compensation under a valued policy is identified by taking the insurable value of the part of the goods lost agreed against the insurable value of the whole of the goods. This sum is then contrasted to the agreed value put in the policy and a right proportion of the agreed value turns into the indemnity payable to the assured. Concerning a partial loss incurred by damage to a part or whole of the goods the measure of compensation is worked out by taking a proportion of the agreed value that is harmonious corresponds with sum of the damaged value of the goods decreased from the gross value the goods would have possessed in their undamaged state.

It was held that the assured in such a situation would be legal to the devaluation in value of the ship caused by the damaged incurred. Moreover, in comparison to section 75 of the MIA the assured in this case is not to be legal indemnified beyond the expected charges of repairing the ship. As to be observed with the exclusion of the first condition, the measure of indemnity concerning partial loss of a vessel is estimated in order to the amortization in value of the ship considering the degree of repairs pledged. Depreciation in the context marine insurance is identified by reducing the damaged value of the ship from the sound value of the ship as these figures stood at the end of the risk.

Protection and indemnity insurance, more commonly documented as "P\&l" insurance, does a P\&I Club give a form of mutual marine insurance (P Anderson).

While a marine insurance company provides "hull and machinery" include for vessel owners, and cargo include for cargo owners, a P\&I Club provides cover for open-ended hazard that traditional insurers are unwilling to insure. Typical P\&I cover holds: a carrier's third-party risks for damage lead to cargo during carriage; (John Dunt) war risks; (Michael D Miller) and danger of environmental damage like oil spills and pollution. In the UK, both traditional insurer and P\&I clubs are depending on the Marine Insurance Act 1906.

A P\&I Club is a mutual insurance association that provides risk pooling, information and depiction for its members. Contrasting a marine insurance company, which presented to its stockholder, a P\&I club reports only to its members. At first, P\&I Club members were typically vessel-owners, ship-operators or demise charterers, but more in recent times bar forwarders and tank operators have been able to unite.

Whiles the assured pays a premium to an insurer for cover, which takes a particular time (say, a year, or a voyage), a P\&l Club member instead pays a "call". This is an amount of money that is put into the Club's pool, a type of "kitty". If, at the end of the year, there are still capitals in the pool, each member will pay a decreased call the following year; but if the Club has made a major payout (say, after an oil spillage) club members will at once have to pay a further call to refill the pool.

These Clubs collaborate to give funds in the event of huge claims using a complex system to indicate liability. 
War risk insurance is a kind of insurance, which includes damage because of acts of war, that containing invasion, insurgency, revolt and snatch. Some policies also include damage because of weapons. It is most commonly practiced in the shipping and aviation industries. War risk insurance generally has two ingredient: War Risk Liability, which includes people and items inside the craft and is computed rely on the indemnity amount; and War Risk Hull, which includes the craft itself and is computed based on the value of the craft. The premium differs rely on the expected stability of the countries to which the ship will travel.

Private war risk insurance policies for aircraft were in the short term made void following the attacks and later reinstated with substantially lower compensations. Following this cancellation, the US federal government starts a terror insurance plan to include commercial airlines. The International Air Transport Association has claimed that airlines operating in states that do not arranged for war risk insurance are at a competitive disadvantage in this ground.

\section{Breaking Down 'War Risk Insurance}

War risk insurance marks the furthermost sense for entities that are mostly depending on the risk of abrupt and violent political changes. For instance, companies operational in politically fickle parts of the world are opened to a high risk of loss from acts of war. War risk insurance can include perils like kidnapping and ransom, emergency discharge, worker hurt, long-term disability and loss or damage of property and cargo. Some war insurance policies also include acts of terrorism, but others consider terrorism and war to be two separate categories of danger.

\section{The insurance does not include:}

(A) Insolvency

(B) Perils included by the RACE II clause which are as following:

lonizing radiations from or contamination with radioactivity from any nuclear fuel or from any nuclear waste or from the combustion of nuclear fuel,

The radioactive, toxic, explosive or other hazardous or contaminating properties of every nuclear installation, reactor or other nuclear assembly or nuclear component thereof,

Every weapon or device employing atomic or nuclear fission and/or fusion or other same as reaction or radioactive force or matter,

The radioactive, toxic, explosive or other hazardous or contaminating properties of any radioactive matter,

Every chemical, biological, bio-chemical, or electromagnetic weapon.

\section{Conclusion}

The purpose of marine insurance has been to empower the ship owner and the buyer and seller of goods to drive their individual business while get rid of themselves, at least partly, of the burdensome financial consequences of their property's being lost or damaged due to the various risks of the high seas. Hence, in other words, marine insurance enhances the essential element of financial security so that the risk of an accident occurring during the transport is not an inhibiting issue in the conduct of international trade. The significance of marine insurance, both to assureds, regarding the security it provides and its cost component in the general economics of running a ship or transporting goods, and to countries, mostly developing countries, in its effect on their balance of payments position, cannot be overstated.

The role of providing compensation regards in civil rights issues, mostly remarkable collision of ships. And this instrument comes true in two faces of companies and marine insurance institute and association of protect and compensate.

Insurance business in a certain sense, through insurance companies will be realized. Generally, marine insurance the insurance holder ship (hull and machinery) product insurance, freight and insurance Civil Liability Insurance of ship collisions. Insurance has a dual nature: 
In the other hand is insurance compensation so include the loss of ship including actual or constructive total loss or partial loss. Besides, save charges and share of joint damage goods are included suitable for the provisions rental insurance and how to compute and pay the fee, owner or tenant of ship has substantial benefit insurance and can insure the damage because of waste with the loss of freight insurance

In the compensation insurance, when insurer paid the loss amount to insured insurer will be deputy of insured to repaying back the amount of money that insurer paid. At the present time, the protect and compensation association which is composed of member ship owners and marine law known as mutual insurance institution action which is arranged for insurance cover a diversity of compensation and their responsibilities. For instance, the remaining amount of civil liability that is getting up from accident and not comprised by insurance company will be included by this association.

\section{References}

[1] Allianz Global Corporate \& Specialty AG, Fritz-Schaeffer-Strasse 9. (2013) General Average and salvage charges, Germany

[2] David, P., Stewart, R. International Logistics: The Management of International Trade Operations - Thomson: Mason, Ohio. 2007 Ch.10-8f - 11/26/2012

[3] Development of laws relating to marine insurance in India Prashanti Upadhyay

[4] English Marine Insurance Act 1906 An Act to codify the Law relating to Marine Insurance [21st December 1906]

[5] Francis D. Rose, Gerard Mc Meel, Stephen Watterson. Marine Insurance: Law and Practice.

[6] Indian Marine Insurance Act, 1963, Section 2(e) (= Section 3(2), English Act of 1906); Thames v. Hamilton, (1887) 12 App. CAs. 484, 498 H.L. (per Lord Herschel).

[7] Insurance law and practice. (2007). C.I.TYAGI MADHU TYAGI,New Delhi-110002.

[8] J. Franklin. The Science of Conjecture: Evidence and Probability Before Pascal .Baltimore: Johns Hopkins University Press.2001.

[9] Jonathan Gilman, Robert Merkin, Claire Blanchard, Mark Templeman. (2013) Arnould's Law of Marine Insurance and Average 18 th ed.UK, Sweet \& Maxwell Ltd

[10] LLP, Law2004. Print.

[11] Marine Cargo Insurance - John Dunt - - Informa - 2009

[12] Marine War Risks - Michael D Miller - - Lloyds - 1994

[13] Martine Remond-Gouilloudlnsurance, Liability and Compensation, Marine Policy. 1990. Print.

[14] Partial Losses (Including Salvage and General Average and Particular Charges) Lloyd's Rep. 338. (See Glossary of Shipping Terms, Maritime Administration, Washington, DC, 2008 www.marad.dot.gov/documents/Glossary_final.pdf A FPA policy covers total losses

[15] Rhidian Thomas, "The concept and measure of indemnity in marine insurance policies", The Mordern Law of $\begin{array}{llll}\text { Marine Insurance. } & \text { Vol. } & \text { 3. http://www.businessdictionary.com/definition/particular- }\end{array}$ average.html\#ixzz4AEJJ4wvG

[16] The Mariner's Guide to Marine Insurance - P Anderson - 1999 - Nautical Institute - ISBN 1870077539 